\title{
PENGARUH KOMPETENSI PEDAGOGIK GURU DALAM MENERAPKAN PEMBELAJARAN KOOPERATIF BERBANTUAN MEDIA PRESENTASI TERHADAP HASIL BELAJAR PESERTA DIDIK PADA MATA PELAJARAN MATEMATIKA
}

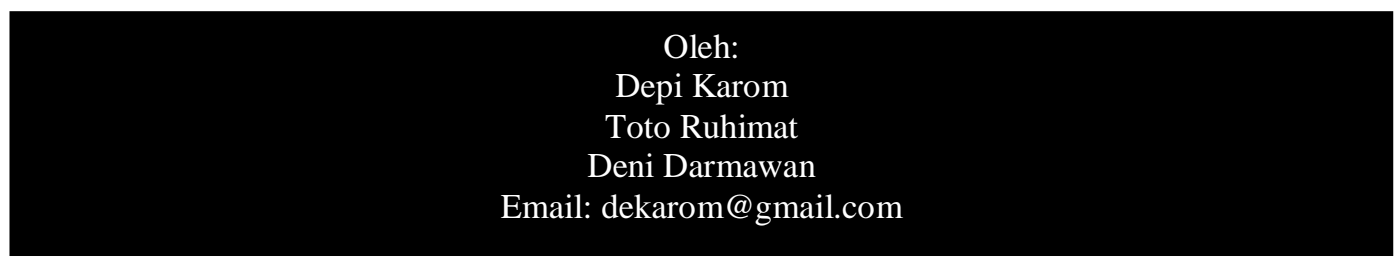

AbstractThe purpose of this study is to obtain an empirical description of 1) the influence of pedagogical competence of teachers to learning outcomes, 2) the effects of cooperative learning on student learning outcomes, and 3) the influence of the media presentation of the learning outcomes of students. This study used a descriptive analytic method with a quantitative approach and experimental design. The study population was a high school student Ma'Arif Peundeuy Class XI Science (IPA and IPA-1-2), amounting to 72 people and sampled the IPA XI-1 as many as 36 people. The tools used to collect data were questionnaires (questionnaire) and tests. Data Analysis in this study using SPSS version 20 and Microsoft Excel 2010.

Based on the data analysis we can see that the learning outcomes are positively and significantly influenced by teachers' pedagogical competence of .520 , whereas the effect of cooperative learning on student learning outcomes are positive and significant at 0.646 and presentation of media influence on student learning outcomes significantly by 0.586 , and when viewed together, the study of students positively and significantly influenced by pedagogical competence of teachers, cooperative learning and media presentations of 0.542 , meaning that the learning outcomes would be higher if the pedagogical competence of teachers in implementing cooperative learning aided presentation media is owned and implemented by all teacher.

Keywords: Media presentation, Competence Pedagogy.

Abstrak Tujuan penelitian ini adalah untuk memperoleh gambaran empiris tentang 1) pengaruh kompetensi pedagogik guru terhadap hasil belajar, 2) pengaruh pembelajaran kooperatif terhadap hasil belajar peserta didik, dan 3) pengaruh media presentasi terhadap hasil belajar peserta didik. Penelitian ini menggunakan metode deskriptif analitik dengan pendekatan kuantitatif dan memiliki desain eksperimen. Populasi penelitian adalah siswa SMA Ma'arif Peundeuy Kelas XI IPA (IPA-1 dan IPA-2) yang berjumlah 72 orang dan yang dijadikan sampel yaitu kelas XI IPA-1 sebanyak 36 orang. Alat yang digunakan untuk mengumpulkan data adalah quisioner (angket) dan tes. Pegolahan data dalam penelitian ini menggunakan program SPSS versi 20 dan program Microsoft Excel 2010.

Berdasarkan analisis data diperoleh gambaran bahwa hasil belajar dipengaruhi secara positif dan signifikan oleh kompetensi pedagogik guru sebesar 0,520, sedangkan pengaruh pembelajaran kooperatif terhadap hasil belajar peserta didik adalah positif dan signifikan sebesar 0,646 dan pengaruh media presentasi terhadap hasil belajar peserta didik secara signifikan sebesar 0,586, serta jika dilihat secara bersama, hasil belajar peserta didik dipengaruhi secara positif dan signifikan oleh kompetensi pedagogik guru, pembelajaran kooperatif dan media presentasi sebesar 0,542, artinya hasil belajar akan tinggi jika kompetensi pedagogik guru dalam menerapkan pembelajaran kooperatif berbantuan media presentasi dimiliki dan dilaksanakan dengan baik oleh semua guru.

Kata Kunci: Media presentasi, Kompetensi Pedagogi. 
Edutech, Tahun 13, Vol.1, No.2, Juni 2014

\section{A. PENDAHULUAN}

Tujuan pendidikan nasional adalah menuju masyarakat yang cerdas, terampil, beriman dan bertaqwa kepada Tuhan Yang Maha Esa, berakhlak mulia, sehat, berilmu, cakap, kreatif, inovatif, mandiri dan menjadi warga negara yang demokratis serta bertanggung jawab. Tujuan tersebut belum sepenuhnya bisa terwujud. Hal ini bisa dilihat dan dirasakan dari output yang dihasilkan masih sangat jauh dari harapan.

Untuk mewujudkan tujuan nasional tersebut, diperlukan sumber daya manusia yang berkualitas dan tenaga pendidik yang profesional termasuk di dalamnya anggaran dari pemerintah yang cukup, dan sistem pendidikan yang handal sehingga berpengaruh terhadap kualitas pembelajaran dan pada akhirnya diharapkan dapat meningkatkan hasil belajar peserta didik. Selain itu juga diharapkan pendidikan dinegara kita dapat menghasilkan lulusan yang mampu berpikir global (think globally), dan mampu bertindak lokal (act localy), serta dilandasi oleh akhlak yang mulia (akhlakul karimah)

Dunia pendidikan saat ini sedang mengalami perubahan sesuai dengan tuntutan dan kebutuhan masyarakat, serta ditantang untuk dapat menjawab berbagai permasalahan lokal maupun perubahan global yang terjadi dengan begitu cepat. Perubahan tersebut mencakup social change, turbulence, comflexity, and chaos dalam menyikapi perubahan tersebut pemerintah melaksanakan pembangunan yang berfokus pada otonomi dengan menyerahkan sebagian wewenang pusat kepada daerah melalui mekanisme otonomi daerah

Pembangunan nasional dibidang pendidikan adalah upaya mencerdaskan kehidupan bangsa dan meningkatkan kualitas manusia Indonesia dalam mewujudkan masyarakat yang maju, adil, dan makmur serta memungkinkan para warganya mengembangkan diri, baik berkenaan dengan aspek jasmaniah maupun rohaniah berdasarkan Pancasila dan Undang-Undang Dasar 1945. Pendirian sekolah-sekolah merupakan perwujudan dari usaha pembangunan nasional dibidang pendidikan, oleh karena itu, sekolah sebagai lembaga pendidikan formal bukan hanya sebagai sistem sosial terbuka, agen perubahan, tempat untuk menyiapkan peserta didik melalui kegiatan bimbingan, pengajaran, dan/atau latihan, namun harus peka menyesuaikan diri dan dapat mengantisipasi perkembanganperkembangan yang akan terjadi dalam kurun waktu tertentu.

\section{Perkembangan-perkembangan}

tersebut dimaksudkan untuk membantu siswa agar lebih mampu menghadapi tantangan hidup, baik pada masa sekarang maupun pada masa yang akan datang. Ini

275 Pengaruh Kompetensi Pedagogik Guru Dalam Menerapkan Pembelajaran Kooperatif Berbantuan Media Presentasi Terhadap Hasil Belajar Peserta Didik Pada Mata Pelajaran 
menunjukan bahwa sekolah merupakan lembaga pendidikan yang sangat penting dalam upaya menumbuhkan dan mengembangkan siswa menjadi individu yang berkualitas di masyarakat.

Untuk menciptakan siswa yang berkualitas sesuai dengan tujuan pendidikan nasional itu bukan hal yang mudah sehingga sampai saat ini belum sepenuhnya terwujudkan, salah satu cirinya adalah masih rendahnya syarat kelulusan yang harus dicapai oleh peserta didik (nilai ujian nasional) jika dibandingkan dengan negara lain. Banyak faktor yang menjadi penentu rendahnya syarat tersebut, seperti di negara kita masih kekurangan guru yang profesional, tidak meratanya penyebaran guru sering terjadinya perubahan kurikulum, kurang lengkapnya sumber belajar sarana dan prasarana yang kurang memadai, iklim pembelajaran yang tidak kondusip, (kreatif, tenang, dan menyenangkan), serta kurang didukung oleh kebijakan (political will) pemerintah, baik dari pusat maupun didaerah. Hal tersebut di atas berdampak pula terhadap kualitas pembelajaran sehingga mengakibatkan rendahnya hasil belajar peserta didik.

Kaitannya dengan pembelajaran yang mampu membawa peserta didik ke dalam situasi pembelajaran yang mempunyai arti sehingga tantangan lokal dan global bisa ditempuh dengan mudah maka pembelajaran di kelaslah yang pertama kali harus diperhatikan, sementara tuntutan pembelajaran di era globalisasi sekarang yang serba canggih serta bukan hanya bersifat kompetitif tapi juga sangat terkait dengan berbagai kemajuan teknologi dan informasi maka kualitas sistem pembelajaran yang dikembangkan harus mampu secara cepat adaptasi dan memperbaiki berbagai kelemahan yang ada. Salah satu solusi yang dapat dikembangkan adalah mengubah sistem pembelajaran konvensional dengan sistem pembelajaran yang lebih efektif dan efisien dengan dukungan sarana dan prasarana yang memadai.

Teknologi pembelajaran memberikan solusi terbaik dalam mengkonversi pembelajaran yang kurang menyenangkan menjadi pembelajaran yang kooperatif, interaktif dan inovatif dengan menggunakan berbagai media teknologi yang canggih, pembelajaran dengan memanfaatkan sarana teknologi informasi melalui media presentasi merupakan salah satu alternatif yang tepat dan dapat mengatasi berbagai persoalan pembelajaran, walaupun sistem pendidikan di Indonesia keberadaannya sangat hetrogen karena terbentur masalah letak geografis yang sangat besar pengaruhnya terhadap kemajuan teknologi informasi.

\section{LANDASAN TEORI}

a. Kompetensi Pedagogik Guru

276 Pengaruh Kompetensi Pedagogik Guru Dalam Menerapkan Pembelajaran Kooperatif Berbantuan Media Presentasi Terhadap Hasil Belajar Peserta Didik Pada Mata Pelajaran Matematika 
Edutech, Tahun 13, Vol.1, No.2, Juni 2014

Demi menghasilkan peserta didik yang berkualitas, maka harus diawali dengan guru memiliki kompetensi yang baik, karena kita tidak bisa menutup mata ada sebuah kenyataan bahwa guru yang kompeten akan menghasilkan peserta didik yang kompeten pula atau kompetensi guru berbanding lurus dengan kualitas peserta didik.

Menurut Mulyasa (2007:125). Kompetensi (competency) didefinisikan dengan berbagai cara, namun pada dasarnya kompetensi merupakan kebulatan penguasaan pengetahuan, keterampilan melalui unjuk kerja, yang diharapkan dapat dicapai seseorang setelah menyelesaikan suatu program pendidikan

Menurut Usman (2002: 145). Kompetensi adalah suatu hal yang menggambarkan kualifikasi atau kemampuan seseorang, baik kualitataif maupun kuantitatif Dari pengertian di atas, mengandung makna bahwa kompetensi dapat digunakan dalam dua konteks, yaitu pertama, sebagai indikator kemampuan seseorang yang menunjukan kepada perbuatan yang diamati; kedua, sebagai konsep yang mencakup ranah kognitif, afektif dan psikomotor.
Menurut Undang-Undang Republik Indonesia Nomor 14 Tahun 2005 tentang Guru dan Dosen, dijelaskan bahwa "Kompetensi adalah seperangkat pengetahuan, keterampilan dan perilaku yang harus dimiliki, dihayati, dan dikuasai oleh guru atau dosen dalam melaksanakan tugas keprofesionalan".

Menurut Muhaemin (dalam Majid, 2006:5) beliau mengemukakan pengertian kompetensi sebagai berikut:

Kompetensi adalah seperangkat tindakan intelegen penuh tanggungjawab yang harus dimiliki oleh seseorang sebagai syarat untuk dianggap mampu melaksanakan tugas-tugas dalam bidang pekerjaan tertentu. Sifat intelegen harus ditunjukan sebagai kemahiran, ketepatan, dan keberhasilan bertindak. Sifat tanggungjawab harus ditunjukan sebagai kebenaran tindakan, baik dipandang dari sudut ilmu pengetahuan, teknologi mapun etika. Dalam arti tindakan itu benar ditinjau dari sudut ilmu pengetahuan, efisiensi, efektif, dan memiliki daya tarik dilihat dari sudut teknologi dan baik ditinjau dari sudut etika.

Pasal 8 Undang-undang Nomor 14 Tahun 2005 tentang Guru dan Dosen menyatakan bahwa. "guru 
Edutech, Tahun 13, Vol.1, No.2, Juni 2014

wajib memiliki kualifikasi akademik, kompetensi, sertifikat pendidik, sehat jasmani dan rohani, serta memiliki kemampuan untuk mewujudkan tujuan pendidikan nasional". Yang dimaksud kompetensi dalam pasal 8 Undang-undang Nomor 14 Tahun 2005 tersebut dijelaskan dalam pasal 10 sebagai berikut, "kompetensi guru sebagaimana dimaksud pasal 8 meliputi kompetensi pedagogik, kompetensi kepribadian, kompetensi sosial, dan kompetensi profesional yang diperoleh melalui pendidikan profesi"

Kompetensi pedagogik adalah kemampuan mengelola pembelajaran peserta didik yang meliputi pemahaman terhadap peserta didik, perancangan dan pelaksanaan pembelajaran, evaluasi hasil belajar dan pengembangan peserta didik untuk mengaktualisasikan berbagai potensi yang dimilikinya dan diperkuat oleh Darmawan (2013:44). One of the main factors in learning process is teachers.

$$
\text { Kompetensi pedagogik }
$$
merupakan kemampuan guru dalam pengelolaan pembelajaran peserta didik yang sekurang-kurangnya meliputi hal-hal sebagai berikut.

a. Pemahaman wawasan atau landasan kependidikan b. Pemahaman terhadap peserta didik

c. Pengembangan kurikulum/silabus

d. Perancangan pembelajaran

e. Pelaksanaan pembelajaran yang mendidik, dialogis dan komunikatif

f. Pemanfaatan teknologi pembelajaran

g. Evaluasi hasil belajar

h. Pengembangan peserta didik untuk mengaktualisasikan berbagai potensi yang dimilikinya

\section{b. Pembelajaran Kooperatif}

Pembelajaran Kooperatif adalah salah satu model pembelajaran matematika yang muncul pada Konferensi Pendidikan Matematika Asia Tenggara ke-8 di Manila pada tahun 1999, dan Annual Meeting National Council of Teachers of Mathematics USA ke 77 di San Fransisco, April 1999. Model kooperatif menekankan pada aspek sosial antar siswa dalam satu kelompok yang heterogen.

Menurut Eggen and Kauchak (dalam Trianto, 2009:58), menyebutkan bahwa pembelajaran kooperatif merupakan sebuah kelompok strategi pengajaran yang melibatkan siswa bekerja secara berkolaborasi untuk mencapai tujuan bersama. 
Edutech, Tahun 13, Vol.1, No.2, Juni 2014

Struktur tujuan kooperatif terjadi jika siswa dapat mencapai tujuan mereka hanya jika siswa lain dengan siapa mereka bekerja sama mencapai tujuan tersebut. Tujuan-tujuan pembelajaran ini mencakup tiga jenis tujuan penting, yaitu hasil belajar, penerimaan terhadap keragaman dan pengembangan keterampilan sosial (Ibrahim, dkk, 2000:7)

Beberapa pendapat di atas mengatakan bahwa belajar kooperatif adalah suatu model pembelajaran dimana siswa belajar dan bekerja dalam kelompok-kelompok kecil secara kolaboratif yang anggotanya empat sampai enam orang, dengan struktur kelompok heterogen. Selain itu dikemukakan juga bahwa model cooperative learning yaitu suatu cara pendekatan atau serangkaian strategi yang khusus dirancang untuk memberi dorongan kepada peserta didik agar bekerja sama selama berlangsungnya proses pembelajaran. Pembelajaran ini juga dapat meningkatkan belajar siswa menuju belajar yang lebih baik dan dapat meningkatkan sikap tolong-menolong dalam perilaku sosial.

Jadi tampaknya belajar dengan model kooperatif sangat tepat diterapkan untuk meningkatkan hasil belajar peserta didik, berani mengemukakan pendapatnya, menghargai pendapat teman, dan saling memberikan pendapat (sharing ideas). Jika dalam belajar Matematika, siswa dihadapkan pada banyaknya soal yang harus dipecahkan dan itu besar kemungkinan tidak bisa dikerjakan hanya oleh sendiri maka belajar kooperatif sangat baik untuk dilaksanakan karena siswa dapat bekerja sama dan saling tolong menolong mengatasi masalah yang dihadapinya. Beberapa ahli menyatakan bahwa model ini tidak hanya unggul dalam membantu siswa memahami konsep yang sulit tetapi juga sangat berguna untuk menumbuhkan kemampuan berpikir kritis, bekerja sama, dan membantu teman.

Agar pembelajaran kooperatif dapat lebih efektif, disarankan agar dalam pembelajaran ditanamkan unsur-unsur dasar belajar kooperatif, yaitu :

1. Siswa harus memiliki persepsi bahwa mereka "tenggelam atau berenang bersama".

2. Siswa memiliki tanggung jawab terhadap tiap siswa lain dalam kelompoknya, disamping tanggung jawab terhadap diri sendiri dalam mempelajari materi yang dihadapi. 
Edutech, Tahun 13, Vol.1, No.2, Juni 2014

3. Siswa harus berpandangan bahwa mereka semuanya memiliki tujuan yang sama.

4. Siswa harus berbagi tugas dan berbagi tanggung jawab sama besarnya di antara para anggota kelompok.

5. Siswa akan diberi suatu evaluasi atau penghargaan, yang lain ikut berpengaruh terhadap evaluasi seluruh kelompok.

6. Siswa berbagi kepemimpinan, sementara mereka memperoleh keterampilan bekerja sama selama belajar.

7. Siswa diminta mempertanggungjawabkan secara individual materi yang dipelajari dalam kelompok kooperatif.

Semua unsur dasar pembelajaran kooperatif mejadi satu kesatuan yang harus dimiliki oleh semua peserta didik dalam proses pembelajaran dan ini menjadi tanggungjawab guru secara mutlak untuk suksesnya keberlangsungan pembelajaran, karena guru merupakan faktor utama suksesnya pembelajaran seperti dikemukakan oleh Darmawan (2013:44). One of the main factors in learning process is teachers. Artinya guru wajib memiliki kompetensi yang cukup untuk mensukseskan pembelajaran kooperatif dan salah satu kompetensi yang berhubungan langsung dengan proses pembelajaran adalah kompetensi pedagogik.

\section{c. Media Presentasi}

Presentasi adalah suatu kegiatan berbicara di hadapan satu orang atau lebih yang biasanya bertemakan bisnis, sosial, pendidikan atau bisa juga tentang kehidupan sehari-hari. Tujuan presentasi adalah memberikan penjelasan tentang suatu ide atau gagasan yang berhubungan dengan proyek, penelitian, karya tulis, promosi produk, pendidikan dan lain sebagainya. (Ninggar, 2011:7).

Kaitannya dalam bidang pendidikan presentasi yang digunakan lebih dominan digunakan untuk menyampaikan materi pelajaran baik kepada siswa maupun kepada guru atau pemangku pendidikan secara umum, sehingga untuk mempermudah penyampaian suatu materi dibutuhkannya media yang disebut dengan media presentasi.

Media presentasi adalah alat yang didesain sedemikian rupa untuk dipertunjukan kepada publik, media presentasi dalam kajian ini berupa Microsoft Power Point yang merupakan aplikasi sangat populer 
Edutech, Tahun 13, Vol.1, No.2, Juni 2014

dan telah banyak digunakan oleh berbagai kalangan untuk membantu dalam melancarkan sebuah kegiatan.

Microsoft Power Point adalah program yang biasa digunakan untuk presentasi pada kegiatan-kegiatan ilmiah hingga bisnis, dimana di dalamnya merupakan pengintegrasian media seperti teks, gambar, grafik suara atau lagu, animasi video atau film kedalam komputer, sampai dapat digunakan sebagai tampilan interaktif.

Dalam microsoft power point sama halnya dengan perangkat lunak pengolah presentasi lainnya, objek, animasi, teks, gambar dan lainnya diposisikan dalam beberapa halaman individual yang disebut dengan "slide".

Menurut Chandra dan Zakaria (2010:108) Untuk lebih rincinya dapat dilihat pada gambar 2. Dari gambar.
2, tampak jelas bahwa power point memiliki beberapa kemampuan, diantaranya menampilkan berbagai objek ke dalam slide, pemberian efek serta dapat berintegrasi dengan program lainnya, sehingga dari penjelasan di atas, power point memberikan bantuan kepada guru dalam menyampaikan materi pelajaran sehingga materi pelajaran yang dikemas dalam power point lebih menarik, interaktif dan dapat menciptakan suasana belajar yang lebih bergairah. Selain membantu kepada guru, power point juga memberikan bantuan kepada peserta didik dalam belajar dimana pola belajar (visual, oudio dan audio visual) peserta didik sangat heterogen. 


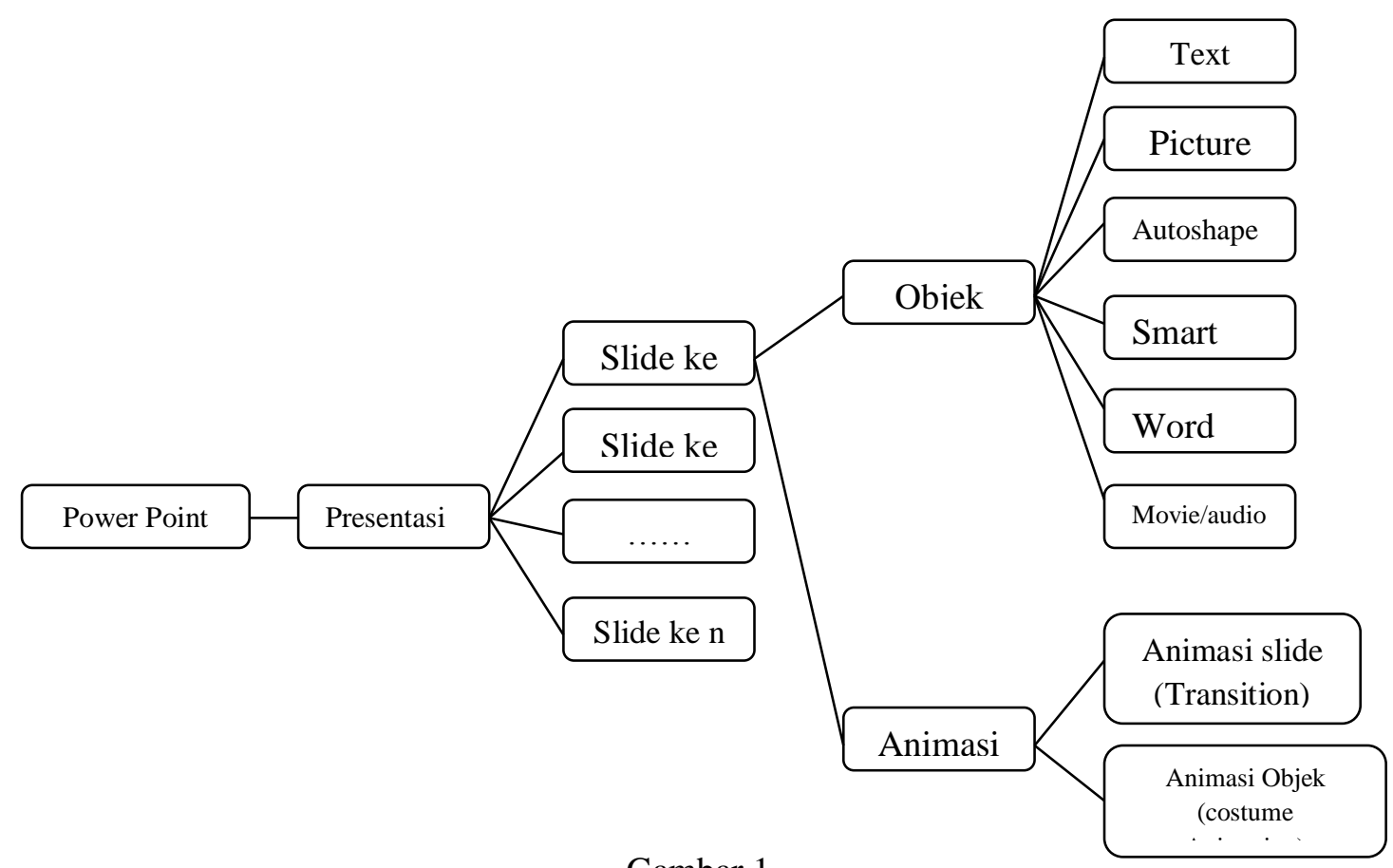

Gambar 1.

Ruang lingkup media presentasi

Dengan power point yang mampu menyajikan materi pelajaran yang menarik perharian peserta didik, maka power point sangat cocok digunakan sebagai media pembantu dalam kegiatan pembelajaran untuk mendapatkan hasil belajar yang memuaskan.

\section{d. Hasil Belajar Peserta Didik}

Hasil belajar adalah kemampuankemampuan yang dimiliki siswa setelah menerima pengalaman belajarnya (Sudjana, 2012 : 22). Sedangkan menurut Kingsley (dalam Sudjana, 2012:22) membagi tiga macam hasil belajar mengajar: (1). Keterampilan dan kebiasaan, (2). Pengetahuan dan pengarahan, (3).
Sikap dan cita-cita. Sedangkan Gagne (dalam Sudjana, 2012:22) membagi menjadi lima kategori hasil belajar, yakni (a) informasi verbal, (b) keterampilan intelektual, (c) strategi kognitif, (d) sikap, dan (e) keterampilan motoris.

Kemudian menurut Samsudin (1987:44), hasil belajar adalah kecakapan nyata atau aktual yang menyatakan kepada aspek kecakapan yang segera dapat didemontrasikan dan diuji karena merupakan hasil usaha yang bersangkutan dengan cara, bahan dan dalam hal tertentu yang dijalaninya.

Dari pendapat para ahli tentang hasil belajar, maka hasil 
Edutech, Tahun 13, Vol.1, No.2, Juni 2014

belajar adalah

kemampuan

keterampilan, sikap dan keterampilan yang diperoleh siswa setelah ia menerima perlakuan yang diberikan oleh guru sehingga dapat mengkonstruksikan pengetahuan itu dalam kehidupan sehari-hari.

Dengan demikian hasil belajar adalah sesuatu yang dicapai atau diperoleh siswa berkat adanya usaha atau pikiran yang mana hal tersebut dinyatakan dalam bentuk penguasaan, pengetahuan dan kecakapan dasar yang terdapat dalam berbagai aspek kehidupa sehingga nampak pada diri indivdu penggunaan penilaian terhadap sikap, pengetahuan dan kecakapan dasar yang terdapat dalam berbagai aspek kehidupan sehingga nampak pada diri individu perubahan tingkah laku secara kuantitatif.

"Belajar adalah suatu perubahan perilaku, akibat interaksi dengan lingkungannya" (Quthb, 2004 : 14). Perubahan perilaku dalam proses belajar terjadi akibat dari interaksi dengan lingkungan. Interaksi biasanya berlangsung secara sengaja. Dengan demikian belajar dikatakan berhasil apabila terjadi perubahan dalam diri individu. Sebaliknya apabila tidak terjadi perubahan dalam diri individu maka belajar tidak dikatakan berhasil.
Hasil belajar yang dicapai siswa dipengaruhi oleh dua faktor yakni faktor dari dalam diri siswa dan faktor dari luar diri siswa (Sudjana, 2004 : 39). Dari pendapat ini faktor yang dimaksud adalah faktor dalam diri siswa perubahan kemampuan yang dimilikinya, faktor dalam diri peserta didik tiada lain adalah kemampuan intelektual peserta didik tersebut, sedangkan faktor dari luar diri siswa yakni lingkungan yang paling dominan berupa kualitas pembelajaran yang di dalamnya terjadi komunilasi peserta didik dengan peserta didik, peserta didik dengan guru, peserta didik dengan media pembelajaran dan komunikasi peserta didik dengan lingkungan sekitar.

Hasil belajar siswa dipengaruhi oleh kamampuan siswa dan kualitas pembelajaran. Kualitas pembelajaran yang dimaksud adalah kompetensi pedagogik yang dimiliki oleh guru. Artinya kemampuan dasar guru baik di bidang kognitif (intelektual), bidang sikap (afektif) dan bidang perilaku (psikomotorik) cukup mempengaruhi pula terhadap keberhasilan belajar peserta didik.

Menurut Slameto (1987: 56) faktor yang mempengaruhi hasil belajar adalah sebagai berikut: 
Edutech, Tahun 13, Vol.1, No.2, Juni 2014

a.Faktor internal

1) Faktor jasmaniah

2) Faktor diantaranya:
a) intelegensi siswa
b) sikap siswa
c) bakat siswa
d) minat siswa
e) motivasi siswa
f) kematangan siswa
g) latihan

b. Faktor eksternal

1) Faktor keluarga, diantaranya
a) Cara orang tua mendidik
b) Relasi antar anggota keluarga
c) Suasana rumah
d) Keadaan ekonomi keluarga

2) Faktor sekolah, diantaranya
a) Interaksi guru dengan murid
b) Cara penyajian guru

Dari beberapa pendapat di atas, maka hasil belajar peserta didik erat kaitannya dengan kemampuuan guru dalam berinteraksi dan penyajian materi dalam pembelajaran, sehingga secara utuh hasil belajar dipengaruhi oleh dua faktor dari dalam individu siswa berupa kemampuan personal (internal) dan faktor dari luar diri siswa yakni lingkungan.

\section{METODE}

Sejalan dengan penelitian yang akan dilakukan yaitu Pengaruh Kompetensi Pedagogik Guru dalam Pembelajaran Kooperatif Berbantuan Media Presentasi terhadap Hasil Belajar Peserta Didik pada Mata Pelajaran Matematika di SMA Ma'arif Peundeuy, maka objek penelitiannya adalah data hasil penelitian tentang kompetensi guru, pembelajaran kooperatif dan media presentasi serta hasil belajar peserta didik

Metode penelitian yang akan digunakan adalah metode penelitian eksperimen. Sugiyono, (2009:107) mengemukakan "metode penelitian eksperimen dapat diartikan sebagai metode penelitian yang digunakan untuk mencari pengaruh perlakuan tertentu terhadap yang lain dalam kondisi yang terkendali”.

Metode penelitian eksperimen merupakan bagian dari metode kuantitatif yang memiliki karakteristik tertentu. Sukmadinata, (2005:12) mengemukakan bahwa "penelitian kuantitatif didasarkan atas konsep positivisme yang bertolak dari asumsi bahwa realita bersifat tunggal, fixed, stabil, lepas dari kepercayaan dan kepercayaan individual. Realita terdiri atas bagian dan unsur yang terpisah satu sama lain dan dapat diukur dengan menggunakan instrumen. 
Edutech, Tahun 13, Vol.1, No.2, Juni 2014

Penelitian ini mengambil jenis eksperimen. Karena dalam hal ini penulis mengadakan manipulasi perlakuan terhadap satu kelompok atau satu kelas. Kelompok tersebut adalah kelompok eksperimen menggunakan model pembelajaran kooperatif berbantuan media presentasi.

Selanjutnya peneliti mencoba membandingkan melalui perhitungan statiktik tentang seberapa besar kontribusi kompetensi pedagogik guru terhadap hasil belajar, seberapa besar kontribusi pembelajaran kooperatif terhadap hasil belajar, dan seberapa besar kontribusi penyajian materi melalui media presentasi terhadap hasil belajar. Hal di atas menunjukan bahwa bereksperimen adalah mengadakan kegiatan percobaan untuk melihat sesuatu hasil. Sedangkan menurut Arikunto (2004:257), penelitian eksperimen merupakan penelitian yang dimaksudkan untuk mengetahui ada tidaknya akibat dari "sesuatu" yang dikenakan pada subjek selidik. Dengan kata lain penelitian eksperimen mencoba meneliti ada tidaknya pengaruh. Caranya adalah dengan melihat seberapa besar pengaruh kompetensi pedagogik guru dalam pembelajaran kooperatif berbantuan media presentasi terhadap hasil belajar peserta didik.

Berdasarkan uraian di atas, maka dapat ditarik kesimpulan bahwa metode eksperimen sesuai digunakan dalam penelitian ini, karena sesuai dengan tujuan penelitian ini yaitu untuk memperoleh gambaran Pengaruh Kompetensi Pedagogik Guru dalam Pembelajaran Kooperatif Berbantuan Media Presentasi Terhadap Hasil Belajar Peserta Didik pada Mata Pelajaran Matematika di SMA Ma'arif Peundeuy

Pada penelitian ini, peneliti mencoba mengungkap sebuah permasalahan dengan menggali data dengan menggunakan alat berupa penyebaran angket untuk mendapatkan data tentang kompetensi pedagogik guru, pembelajaran kooperatif dan media presentasi, sementara untuk melihat kemampuan siswa pada hasil belajar peneliti menggunakan alat pengumpul data berupa tes tulis dan dalam rangka menganalisis data hasil penelitian, peneliti menggunakan uji validitas, reliabilitas, daya pembeda, indeks kesukaran, regresi parcial, multiple regresi dan path analisys.

\section{B. HASIL PENELITIAN DAN PEMBAHASAN}

\section{Hasil Penelitian}

\section{a. Kompetensi Pedagogik Guru Terhadap Hasil Belajar Peserta Didik}

Hipotesis yang diajukan adalah " terdapat pengaruh yang signifikan antara kompetensi 
Edutech, Tahun 13, Vol.1, No.2, Juni 2014

pedagogik guru terhadap hasil belajar peserta didik".

$$
\text { Hipotesis statistiknya }
$$

sebagai berikut.

$$
\begin{aligned}
& H_{0}: \rho X_{1} Y=0 \\
& H_{a}: \rho X_{1} Y \neq 0
\end{aligned}
$$

Sedangkan hipoteis penelitiannya adalah sebagai berikut.

$\mathrm{H}_{\mathrm{o}}$ : tidak terdapat pengaruh yang signifikan antara kompetensi pedagogik guru terhadap hasil belajar peserta didik
$\mathrm{H}_{\mathrm{a}}$ : terdapat pengaruh yang signifikan antara kompetensi pedagogik guru terhadap hasil belajar belajar peserta didik

Hasil pengolahan data dengan program SPSS Versi 20 tentang analisis jalur dan uji regresi antara variabel Kompetensi Pedagogik Guru $\left(\mathrm{X}_{1}\right)$ dengan Hasil Belajar Peserta Didik (Y) sebagai berikut.

Tabel 1

Koefesien dan Konstanta Persamaan Garis Regresi Variabel $\mathrm{X}_{1}$ terhadap Y

\section{Regression}

Variables Entered/Removed ${ }^{\mathrm{a}}$

\begin{tabular}{|l|l|c|l|}
\hline Model & \multicolumn{1}{|c|}{$\begin{array}{c}\text { Variables } \\
\text { Entered }\end{array}$} & $\begin{array}{c}\text { Variables } \\
\text { Removed }\end{array}$ & Method \\
\hline 1 & $\mathrm{X}_{-} 1^{\mathrm{b}}$ & & Enter \\
\hline
\end{tabular}

a. Dependent Variable: Y

b. All requested variables entered. 
(a)

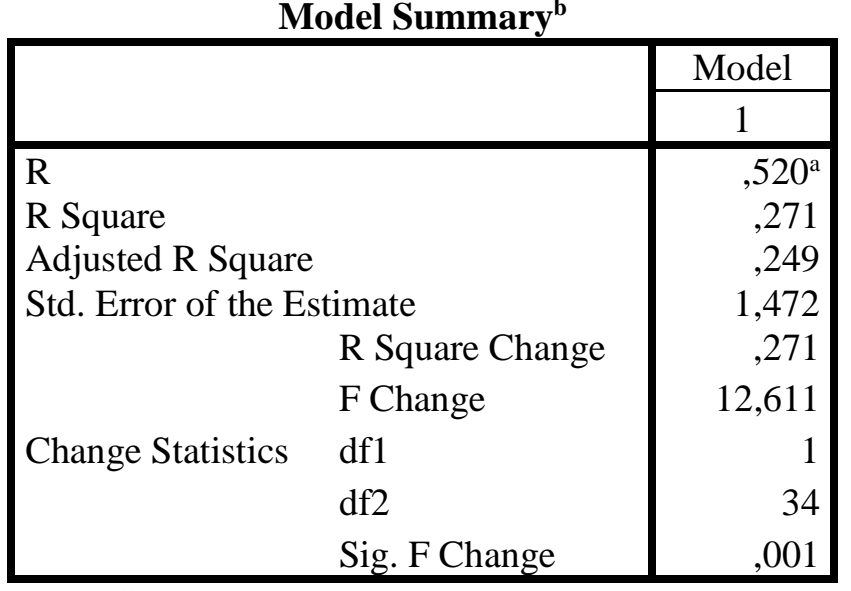

a. Predictors: (Constant), X_1

b. Dependent Variable: Y

(b)

Coefficients $^{\mathrm{a}}$

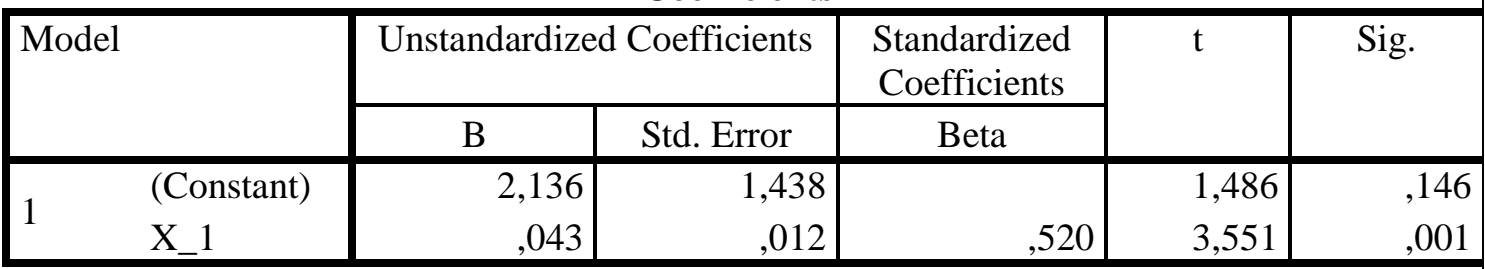

a. Dependent Variable: $\mathrm{Y}$

Pengaruh antara variabel

(c)

kompetensi pedagogik guru $\left(\mathrm{X}_{1}\right)$

kompetensi pedagogik guru

terhadap hasil belajar peserta didik

(Y) sebesar $\operatorname{pyx}_{1}=0,520$ (tabel 1 .

(variabel $\mathrm{X}_{1}$ ) dan sisanya $12,5 \%$

dipengaruhi oleh variabel lain.

Dengan menggunakan tabel 1.

(b)) tergolong kuat. Sedangkan

(c) maka didapat persamaan garis

untuk menyatakan besar kecilnya

$\hat{\mathrm{Y}}=\mathrm{a}+\mathrm{b} \mathrm{X}_{1}$ adalah $\hat{\mathrm{Y}}=2,136+$

kontribusi (sumbangan variabel $\mathrm{X}_{1}$

$0,043 \mathrm{X}_{1}$, arti dari persamaan

terhadap Variabel Y) yaitu dengan

tersebut adalah "jika terjadi

menghitung koefesien determinasi

perubahan nilai kompetensi

dengan rumus $\mathrm{KP}=\mathrm{r}^{2} \mathrm{x} 100 \%$ atau

pedagogik guru $\left(\mathrm{X}_{1}\right)$ sebesar satu

dengan melihat R Square x $100 \%$,

satuan variabel $\mathrm{X}_{1}$ maka akan

perhitungannya sebagai berikut mengakibatkan naiknya variabel

$0,271 \times 100 \%=27,1 \%$, artinya

hasil belajar (Y) sebesar 0,043".

$27,1 \%$ hasil belajar peserta didik

Selanjutnya dari persamaan $\hat{Y}$

(variabel Y) dipengaruhi oleh

$=2,136+0,043 \mathrm{X}_{1}, \quad$ untuk 
Edutech, Tahun 13, Vol.1, No.2, Juni 2014

mengetahui apakah model persamaan regresi tersebut dapat digunakan untuk menarik kesimpulan secara signifikan atau tidak, dapat dilihat nilai signifikansi pada tabel 1. (c). Signifikansi $\mathrm{X}_{1}$ terhadap $\mathrm{Y}$ diketahui dengan membandingkan sig. $0,00<\alpha=0,05$, artinya pada tingkat kesalahan kurang dari 5\% variabel hasil belajar (Y) secara signifikan dipengaruhi oleh variabel kompetensi pedagogik guru $\left(\mathrm{X}_{1}\right)$, maka hasil analisis regresi tersebut berakibat kepada ditolak $\mathrm{H}_{0}$ dan diterimanya $\mathrm{H}_{\mathrm{a}}$ sehingga dapat disimpulkan bahwa terdapat pengaruh yang signifikan antara kompetensi pedagogik guru terhadap hasil belajar peserta didik

\section{c. Pembelajaran Kooperatif Terhadap Hasil Belajar Peserta Didik}

Hipotesis yang diajukan adalah " terdapat pengaruh yang signifikan antara pembelajaran

Tabel 2

Koefesien dan Konstanta Persamaan Garis Regresi Variabel $\mathrm{X}_{2}$ terhadap Y

\section{Regression}

\begin{tabular}{|l|l|c|l|}
\multicolumn{4}{c}{ Variables Entered/Removed $^{\mathrm{a}}$} \\
\hline Model & $\begin{array}{c}\text { Variables } \\
\text { Entered }\end{array}$ & $\begin{array}{c}\text { Variables } \\
\text { Removed }\end{array}$ & Method \\
\hline 1 & $\mathrm{X} 2^{\mathrm{b}}$ & & Enter \\
\hline
\end{tabular}

a. Dependent Variable: Y

288 Pengaruh Kompetensi Pedagogik Guru Dalam Menerapkan Pembelajaran Kooperatif Berbantuan Media Presentasi Terhadap Hasil Belajar Peserta Didik Pada Mata Pelajaran Matematika kooperatif terhadap hasil belajar

Hipotesis statistiknya

sebagai berikut.

$$
\begin{aligned}
& H_{\mathrm{o}}: \rho \mathrm{X}_{2} \mathrm{Y}=0 \\
& \mathrm{H}_{\mathrm{a}}: \rho \mathrm{X}_{2} \mathrm{Y} \neq 0
\end{aligned}
$$

Sedangkan hipoteis penelitiannya adalah sebagai berikut.

$\mathrm{H}_{\mathrm{o}}$ : tidak terdapat pengaruh yang signifikan antara pembelajaran kooperatif terhadap hasil belajar peserta didik

$\mathrm{H}_{\mathrm{a}}$ : terdapat pengaruh yang signifikan antara pembelajaran kooperatif terhadap hasil belajar belajar peserta didik

Hasil pengolahan data dengan program SPSS Versi 20 tentang analisis jalur dan uji regresi antara variabel Pembelajaran Kooperatif $\left(\mathrm{X}_{2}\right)$ dengan Hasil Belajar Peserta Didik (Y) sebagai berikut. peserta didik". 
b. All requested variables entered.

(a)

Model Summary ${ }^{b}$

\begin{tabular}{|c|c|c|}
\hline & Model \\
\hline & & 1 \\
\hline \multicolumn{2}{|l|}{$\mathrm{R}$} &, $646^{\mathrm{a}}$ \\
\hline \multicolumn{2}{|l|}{ R Square } & ,418 \\
\hline \multicolumn{2}{|l|}{ Adjusted R Square } & ,401 \\
\hline \multicolumn{2}{|c|}{ Std. Error of the Estimate } & 1,315 \\
\hline & R Square Change & ,418 \\
\hline & F Change & 24,415 \\
\hline \multirow[t]{3}{*}{ Change Statistics } & df1 & 1 \\
\hline & df2 & 34 \\
\hline & Sig. F Change &, 000 \\
\hline
\end{tabular}

a. Predictors: (Constant), X_2

b. Dependent Variable: Y

(b)

Coefficients $^{\mathrm{a}}$

\begin{tabular}{|rl|r|r|r|r|r|}
\hline \multicolumn{2}{|l|}{ Model } & \multicolumn{2}{|c|}{ Unstandardized Coefficients } & \multicolumn{1}{|c|}{$\begin{array}{c}\text { Standardized } \\
\text { Coefficients }\end{array}$} & \multirow{2}{*}{ Sig. } \\
\cline { 3 - 5 } & (Constant) & \multicolumn{1}{|c|}{ B } & Std. Error & \multicolumn{1}{c|}{ Beta } & & \\
\hline \multirow{2}{*}{1} & $-1,111$ & 1,689 & &,- 657 &, 515 \\
& X_2 &, 067 &, 014 &, 646 & 4,941 &, 000 \\
\hline
\end{tabular}

a. Dependent Variable: $\mathrm{Y}$

(c)

Pengaruh antara variabel perhitungannya sebagai berikut

Pembelajaran Kooperatif $\left(X_{2}\right) \quad 0,418 \times 100 \%=41,8 \%$, artinya

terhadap hasil belajar peserta didik $\quad 41,8 \%$ hasil belajar peserta didik

(Y) sebesar $\rho x_{2}=0,646$ (tabel

(variabel Y) dipengaruhi oleh

2.(b) tergolong kuat. Sedangkan pembelajaran kooperatif (variabel untuk menyatakan besarkecilnya $\mathrm{X}_{2}$ ) dan sisanya $58,2 \%$ dipengaruhi kontribusi (sumbangan variabel $\mathrm{X}_{2}$ terhadap Variabel Y) yaitu dengan oleh variabel lain.

Dengan menggunakan tabel 2. menghitung koefesien determinasi (c) maka didapat persamaan garis dengan rumus $\mathrm{KP}=\mathrm{r}^{2} \times 100 \%$ atau $\hat{\mathrm{Y}}=\mathrm{a}+\mathrm{b} \mathrm{X}_{2}$ adalah $\hat{\mathrm{Y}}=-1,111+$ dengan melihat R Square x 100\%, $0,067 \mathrm{X}_{2}$, arti dari persamaan 
Edutech, Tahun 13, Vol.1, No.2, Juni 2014

tersebut adalah "jika terjadi perubahan nilai pembelajaran kooperatif $\left(\mathrm{X}_{2}\right)$ sebesar satu satuan variabel $\mathrm{X}_{2}$ maka akan mengakibatkan naiknya variabel hasil belajar (Y) sebesar 0,067”.

Selanjutnya dari persamaan $\hat{Y}$ $=-1,111+0,067 \mathrm{X}_{2}, \quad$ untuk mengetahui apakah model persamaan regresi tersebut dapat digunakan untuk menarik kesimpulan secara signifikan atau tidak, dapat dilihat nilai signifikansi pada tabel 2. (c). Signifikansi $\mathrm{X}_{2}$ terhadap $\mathrm{Y}$ diketahui dengan membandingkan sig. $0,000<\alpha=0,05$, artinya pada tingkat kesalahan kurang dari 5\% variabel hasil belajar (Y) secara signifikan dipengaruhi oleh variabel pembelajaran kooperatif $\left(\mathrm{X}_{2}\right)$, maka hasil analisis regresi tersebut berakibat kepada ditolak $\mathrm{H}_{0}$ dan diterimanya $\mathrm{H}_{\mathrm{a}}$ sehingga dapat disimpulkan bahwa terdapat pengaruh yang signifikan antara pembelajaran kooperatif terhadap hasil belajar peserta didik

Tabel 3

Koefesien dan Konstanta Persamaan Garis Regresi Variabel $\mathrm{X}_{3}$ terhadap Y

\section{d. Media Presentasi Terhadap Hasil Belajar Peserta Didik}

Hipotesis yang diajukan adalah " terdapat pengaruh yang signifikan antara media presentasi terhadap hasil belajar peserta didik".

Hipotesis statistiknya sebagai berikut.

$$
\begin{aligned}
& H_{\mathrm{o}}: \rho \mathrm{X}_{3} \mathrm{Y}=0 \\
& \mathrm{H}_{\mathrm{a}}: \rho \mathrm{X}_{3} \mathrm{Y} \neq 0
\end{aligned}
$$

Sedangkan hipoteis penelitiannya adalah sebagai berikut.

$\mathrm{H}_{\mathrm{o}}$ : tidak terdapat pengaruh yang signifikan antara media presentasi terhadap hasil belajar peserta didik $\mathrm{H}_{\mathrm{a}}$ : terdapat pengaruh yang signifikan antara media presentasi terhadap hasil belajar belajar peserta didik

Hasil pengolahan data dengan program SPSS Versi 20 tentang analisis jalur dan uji regresi antara variabel Media presentasi $\left(\mathrm{X}_{3}\right)$ dengan Hasil Belajar Peserta Didik (Y) sebagai berikut. 


\section{Regression}

\begin{tabular}{|l|l|c|l|}
\multicolumn{5}{c|}{ Variables Entered/Removed $^{\text {a }}$ Model } & $\begin{array}{c}\text { Variables } \\
\text { Entered }\end{array}$ & $\begin{array}{c}\text { Variables } \\
\text { Removed }\end{array}$ & Method \\
\hline 1 & X_3 & & Enter \\
\hline
\end{tabular}

a. Dependent Variable: Y

b. All requested variables entered.

(a)

\begin{tabular}{|c|c|c|}
\hline & Model \\
\hline & & 1 \\
\hline \multicolumn{2}{|l|}{$\mathrm{R}$} &, $586^{\mathrm{a}}$ \\
\hline \multicolumn{2}{|l|}{ R Square } & ,344 \\
\hline \multicolumn{2}{|c|}{ Adjusted R Square } &, 324 \\
\hline \multicolumn{2}{|c|}{ Std. Error of the Estimate } & 1,396 \\
\hline & R Square Change & ,344 \\
\hline & F Change & 17,793 \\
\hline \multirow[t]{3}{*}{ Change Statistics } & df1 & 1 \\
\hline & df2 & 34 \\
\hline & Sig. F Change &, 000 \\
\hline
\end{tabular}

a. Predictors: (Constant), X_3

b. Dependent Variable: Y

(b)

Coefficients $^{\mathrm{a}}$

\begin{tabular}{|c|c|c|c|c|c|c|}
\hline \multirow{2}{*}{\multicolumn{2}{|c|}{ Model }} & \multicolumn{2}{|c|}{ Unstandardized Coefficients } & Standardized & \multirow[t]{2}{*}{$\mathrm{t}$} & \multirow[t]{2}{*}{ Sig. } \\
\hline & & $\mathrm{B}$ & Std. Error & Beta & & \\
\hline \multirow{2}{*}{1} & (Constant) & $-1,119$ & 1,978 & &,- 566 & ,575 \\
\hline & $X \_3$ &, 069 & 016 & ,586 & 4,218 &, 000 \\
\hline
\end{tabular}

(c)

Pengaruh antara variabel dengan rumus $\mathrm{KP}=\mathrm{r}^{2} \mathrm{x} 100 \%$ atau Media Presentasi $\left(\mathrm{X}_{3}\right)$ terhadap dengan melihat R Square x 100\%, hasil belajar peserta $\operatorname{didik}(\mathrm{Y})$ perhitungannya sebagai berikut sebesar $\rho x_{3}=0,586$ (tabel 3.(b)) $0,344 \times 100 \%=34,4 \%$, artinya tergolong kuat. Sedangkan untuk $34,4 \%$ hasil belajar peserta didik menyatakan besarkecilnya (variabel Y) dipengaruhi oleh kontribusi (sumbangan variabel $\mathrm{X}_{3}$ media presentasi (variabel $\mathrm{X}_{3}$ ) dan terhadap Variabel Y) yaitu dengan sisanya $65,6 \%$ dipengaruhi oleh menghitung koefesien determinasi variabel lain. 
Edutech, Tahun 13, Vol.1, No.2, Juni 2014

Dengan menggunakan tabel 3.

(c) maka didapat persamaan garis $\hat{\mathrm{Y}}=\mathrm{a}+\mathrm{b} \mathrm{X}_{2}$ adalah $\hat{\mathrm{Y}}=-1,119+$ 0,069 $\mathrm{X}_{3}$, arti dari persamaan tersebut adalah "jika terjadi perubahan nilai media presentasi $\left(X_{3}\right)$ sebesar satu satuan variabel $\mathrm{X}_{3}$ maka akan mengakibatkan naiknya variabel hasil belajar (Y) sebesar 0,069".

Selanjutnya dari persamaan $\hat{Y}=$ $1,119+0,069 \quad \mathrm{X}_{3}, \quad$ untuk mengetahui apakah model persamaan regresi tersebut dapat digunakan untuk menarik kesimpulan secara signifikan atau tidak, dapat dilihat nilai signifikansi pada tabel 4.20 (c). Signifikansi $\mathrm{X}_{3}$ terhadap $\mathrm{Y}$ diketahui dengan membandingkan sig. $0,000<\alpha=0,05$, artinya pada tingkat kesalahan kurang dari 5\% variabel hasil belajar (Y) secara signifikan dipengaruhi oleh variabel media presentasi $\left(\mathrm{X}_{3}\right)$, maka hasil analisis regresi tersebut berakibat kepada ditolak $\mathrm{H}_{0}$ dan diterimanya $\mathrm{H}_{\mathrm{a}}$ sehingga dapat disimpulkan bahwa terdapat pengaruh yang signifikan antara media presentasi terhadap hasil belajar peserta didik.

\section{e. Kompetensi Pedagogik, Pembelajaran Kooperatif dan} Berbantuan Media Presentasi Terhadap Hasil Belajar Peserta Didik Pada Mata Pelajaran Matematika

Media Presentasi Terhadap Hasil Belajar Peserta didik

Hipotesis yang diajukan adalah " terdapat pengaruh yang signifikan antara kompetensi pedagogik guru, pembelajaran kooperatif dan media presentasi terhadap hasil belajar peserta didik".

Hipotesis statistiknya sebagai berikut.

$$
\begin{aligned}
& H_{o}: \rho X_{1} X_{2} X_{3} Y=0 \\
& H_{a}: \rho X_{1} X_{2} X_{3} Y \neq 0
\end{aligned}
$$

Sedangkan hipoteis penelitiannya adalah sebagai berikut.

$\mathrm{H}_{\mathrm{o}}$ : tidak terdapat pengaruh yang signifikan antara kompetensi pedagogik guru, pembelajaran kooperatif dan media presentasi terhadap hasil belajar peserta didik

$\mathrm{H}_{\mathrm{a}}$ : terdapat pengaruh yang signifikan antara kompetensi pedagogik guru, pembelajaran kooperatif dan media presentasi terhadap hasil belajar belajar peserta didik

Hasil pengolahan data dengan program SPSS Versi 20 tentang analisis jalur dan uji regresi antara

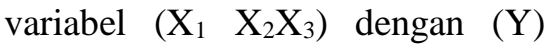
sebagai berikut. 
Tabel 4.

Koefesien dan Konstanta Persamaan Garis Regresi Variabel $\mathrm{X}_{1} \mathrm{X}_{2} \mathrm{X}_{3}$ terhadap Y

\section{Regression}

\begin{tabular}{|l|l|c|l|}
\multicolumn{5}{c}{ Variables Entered/Removed $^{\mathrm{a}}$} \\
\hline Model & \multicolumn{1}{|l|}{$\begin{array}{l}\text { Variables } \\
\text { Entered }\end{array}$} & $\begin{array}{c}\text { Variables } \\
\text { Removed }\end{array}$ & Method \\
\hline 1 & $\begin{array}{l}\text { X_3, X_1, } \\
\text { X_2 }\end{array}$ & & Enter \\
\hline
\end{tabular}

a. Dependent Variable: $\mathrm{Y}$

b. All requested variables entered.

(a)

Model Summary ${ }^{b}$

\begin{tabular}{|c|c|c|}
\hline & Model \\
\hline & & 1 \\
\hline \multirow{4}{*}{\multicolumn{2}{|c|}{$\begin{array}{l}\mathrm{R} \\
\mathrm{R} \text { Square } \\
\text { Adjusted R Square } \\
\text { Std Error of the Estimate }\end{array}$}} &, $736^{\mathrm{a}}$ \\
\hline & &, 542 \\
\hline & & ,499 \\
\hline & Std. Error of the Estimate & 1,203 \\
\hline & R Square Change &, 542 \\
\hline & F Change & 12,601 \\
\hline \multirow[t]{3}{*}{ Change Statistics } & df1 & 3 \\
\hline & df 2 & 32 \\
\hline & Sig. F Change & 000 \\
\hline
\end{tabular}

a. Predictors: (Constant), X_3, X_1, X_2

b. Dependent Variable: Y

(b)

Coefficients $^{\mathbf{a}}$

\begin{tabular}{|c|c|c|c|c|c|}
\hline \multirow[t]{2}{*}{ Model } & \multicolumn{2}{|c|}{$\begin{array}{l}\text { Unstandardized } \\
\text { Coefficients }\end{array}$} & $\begin{array}{l}\text { Standardized } \\
\text { Coefficients }\end{array}$ & \multirow[t]{2}{*}{$\mathrm{t}$} & \multirow[t]{2}{*}{ Sig. } \\
\hline & $\mathrm{B}$ & $\begin{array}{l}\text { Std. } \\
\text { Error }\end{array}$ & Beta & & \\
\hline \multirow{4}{*}{$\begin{array}{l}\text { (Constant) } \\
\text { X_1 } \\
\text { X_2 } \\
\text { X_3 }\end{array}$} & $-4,156$ & 1,890 & & $-2,199$ & 035 \\
\hline &, 023 &, 011 & ,279 & 2,069 &, 047 \\
\hline & ,035 & ,017 & ,336 & 2,092 & ,045 \\
\hline & ,036 & ,017 & ,306 & 2,049 & ,049 \\
\hline
\end{tabular}

a. Dependent Variable: $\mathrm{Y}$

Pengaruh antara variabel (c)
Pengaruh antara variabel
pembelajaran kooperatif dan media
kompetensi pedagogik guru,
presentasi $\left(\mathrm{X}_{3}\right)$ secara bersama-

293 Pengaruh Kompetensi Pedagogik Guru Dalam Menerapkan Pembelajaran Kooperatif

Berbantuan Media Presentasi Terhadap Hasil Belajar Peserta Didik Pada Mata Pelajaran 
Edutech, Tahun 13, Vol.1, No.2, Juni 2014

sama terhadap hasil belajar peserta $\operatorname{didik}(\mathrm{Y})$ sebesar $\rho \mathrm{x}_{1} \mathrm{x}_{2} \mathrm{x}_{3} \mathrm{y}=0,736$ (tabel 4.(b)) tergolong sangat kuat. Sedangkan untuk menyatakan besarkecilnya kontribusi (sumbangan variabel $\mathrm{X}_{1} \quad \mathrm{X}_{2} \quad \mathrm{X} 3$ ) terhadap Variabel $\mathrm{Y}$ ) yaitu dengan menghitung koefesien determinasi dengan rumus $\mathrm{KP}=\mathrm{r}^{2} \times 100 \%$ atau dengan melihat R Square x 100\%, perhitungannya sebagai berikut $0,542 \times 100 \%=54,2 \%$, artinya $54,2 \%$ hasil belajar peserta didik (variabel Y) dipengaruhi oleh kompetensi pedagogik guru, pembelajaran kooperatif dan media presentasi (variabel $\mathrm{X}_{1} \mathrm{X}_{2} \mathrm{X}_{3}$ ) dan sisanya $45,8 \%$ dipengaruhi oleh variabel lain.

Dengan menggunakan tabel 4. (c) maka didapat persamaan garis $\hat{Y}=a+b X_{2}$ adalah $\hat{Y}=-4,156+$ $0,023 X_{1}+0,035 X_{2}+0,036 X_{3}$, arti dari persamaan tersebut adalah "jika terjadi perubahan nilai kompetensi pedagogik guru $\left(\mathrm{X}_{1}\right)$, pembelajaran kooperatif $\left(\mathrm{X}_{2}\right)$ dan media presentasi $\left(\mathrm{X}_{3}\right)$ sebesar satu satuan maka akan mengakibatkan naiknya variabel hasil belajar (Y) sebesar koefesien tiap variabel independen".
Selanjutnya dari persamaan $\hat{Y}=$ $4,156+0,023 X_{1}+0,035 X_{2}+$ $0,036 \mathrm{X}_{3}$, untuk mengetahui apakah model persamaan regresi tersebut dapat digunakan untuk menarik kesimpulan secara signifikan atau tidak, dapat dilihat nilai signifikansi pada tabel 4. (c). Signifikansi $\mathrm{X}_{1} \mathrm{X}_{2} \mathrm{X}_{3}$ terhadap $\mathrm{Y}$ diketahui dengan membandingkan sig. $0,000<\alpha=0,05$, artinya pada tingkat kesalahan kurang dari 5\% variabel hasil belajar (Y) secara signifikan dipengaruhi oleh kompetensi pedagogik guru, pembelajaran kooperatif dan media presentasi, maka hasil analisis regresi tersebut berakibat kepada ditolak $\mathrm{H}_{0}$ dan diterimanya $\mathrm{H}_{\mathrm{a}}$ sehingga dapat disimpulkan bahwa terdapat pengaruh yang signifikan antara kompetensi pedagogik guru, pembelajaran kooperatif dan media presentasi terhadap hasil belajar peserta didik.

Merujuk pada hasil pengujian hipotesis yang telah diuraikan sebelumnya, maka diperoleh diagram empiris antar variabel sebagai berikut. 


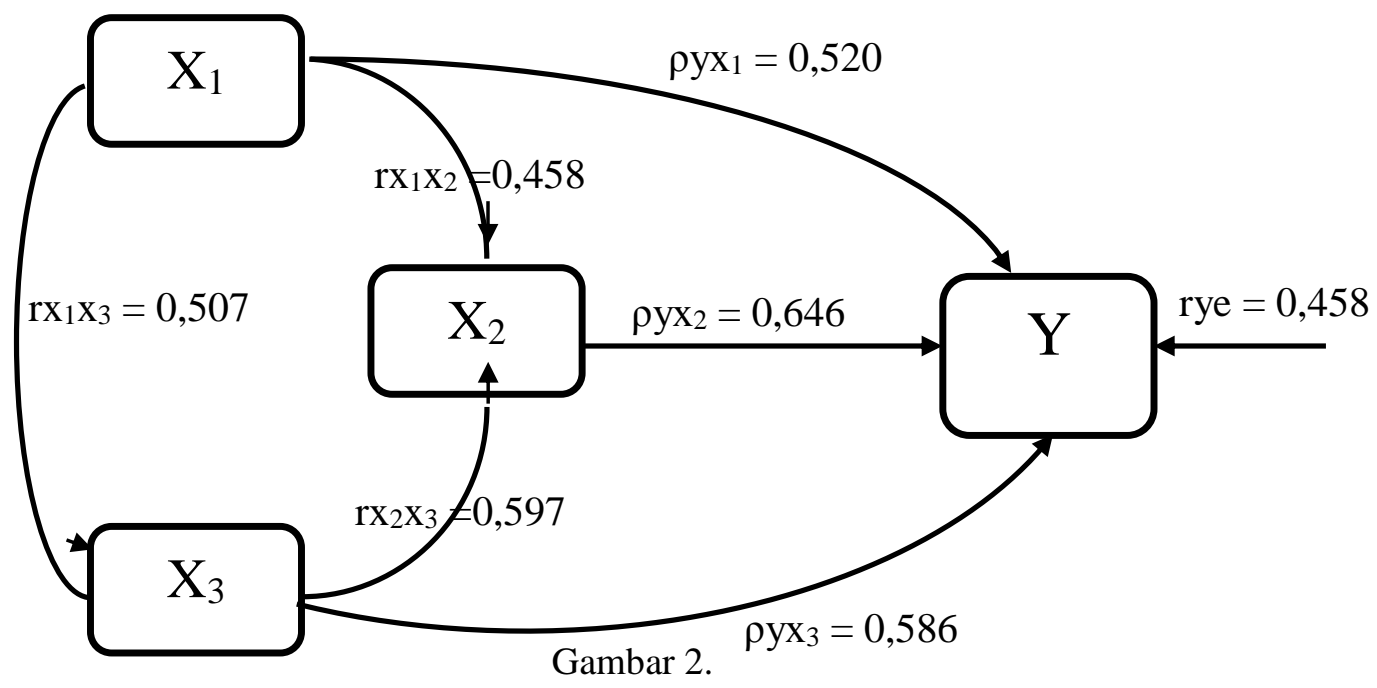

Diagram Empiris Antar Variabel

Berdasarkan pengujian hipotesis dan gambar 2., peneliti dapat menginformasikan sebagai berikut.

1. Diperoleh koefesien R sebesar 0,736 dengan nilai sig. = $0,000<\alpha=0,05$, artinya variabel hasil belajar (Y) secara signifikan dipengaruhi bersama oleh variabel kompetensi pedagogik guru $\left(\mathrm{X}_{1}\right)$, pembelajaran kooperatif $\left(\mathrm{X}_{2}\right)$ dan media presentasi $\left(\mathrm{X}_{3}\right)$

2. Variasi yang terjadi pada variabel hasil belajar peserta didik (Y) bisa dijelaskan secara bersama oleh $\mathrm{X}_{1}, \mathrm{X}_{2}$, dan $\mathrm{X}_{3}$ sebesar $54,2 \%$ sisanya $45,8 \%$ dipengaruhi oleh variabel lain

\section{Pembahasan}

Pembahasan hasil penelitian bertujuan untuk memberikan penjelasan dan elaborasi hasil penelitian, baik hasil analisis deskriptif maupun hasil pengujian hipotesis. Pada analisis deskriptif dilakukan satu demi satu terhadap variabel kompetensi pedagogik guru $\left(\mathrm{X}_{1}\right)$, variabel pembelajaran kooperatif $\left(\mathrm{X}_{2}\right)$, variabel media presentasi $\left(\mathrm{X}_{3}\right)$ dan variabel hasil belajar peserta didik (Y). Sedangkan hasil pengujian hipotesis dengan menggunakan analisis jalur (path analisys) dan regresi sederhana maupun regresi ganda yaitu mengungkap korelasi dan regresi antar variabel $\mathrm{X}_{1}, \mathrm{X}_{2}$, $\mathrm{X}_{3}$, dan $\mathrm{Y}$. 
Edutech, Tahun 13, Vol.1, No.2, Juni 2014

1. Pengaruh Kompetensi

Pedagogik Guru dalam

Menerapkan Pembelajaran

\section{kooperatif Berbantuan}

Media Presentasi terhadap

\section{Hasil Belajar Peserta Didik}

Dari hasil analisis jalur dan regresi, koefesien jalur variabel kompetensi pedagogik guru terhadap hasil belajar peserta didik sebesar 0,520 dengan persamaan regresi $\hat{Y}=2,136+0,043 X_{1}$.

Hasil analisis statistik tersebut menunjukan bahwa kompeteni pedagogik guru memberikan kontribusi positif dan signifikan terhadap hasil belajar peserta didik. Artinya semakin tinggi kompetensi pedagogik guru akan mengakibatkan hasil belajar peserta didik akan semakin tinggi dan sebaliknya penurunan kompetensi pedagogik guru akan mengakibatkan penurunan hasil belajar peserta didik.

Hasil analisis tersebut sejalan dengan pendapat Mulyasa (2007:136) yang menyatakan bahwa "kompetensi pedagogik berhubungan langsung dengan kemampuan individu guru

dalam pemahaman dan pengembangan siswa untuk mengaktualisasikan berbagai potensi siswa melalui pembelajaran yang mendidik dan berakibat langsung pada peningkatan prestasi belajar siswa. Mulyasa (2012: 94) memperkuat pendapat ini dengan pernyataan bahwa kreativitas peserta didik dalam belajar sangat bergantung pada kreativitas guru dalam mengembangkan standar kompetensi, kompetensi dasar dan materi standar serta menciptakan lingkungan belajar yang kondusif.

Dilain pihak manfaat kompetensi pedagogik guru juga mampu meningkatkan kualitas sekolah, karena dengan banyaknya guru yang memiliki kompetensi pedagogik sudah bisa dipastikan akan memberikan kontribusi yang baik terhadap sekolah serta pada akhirnya memberikan dampak positif terhadap peningkatan kualitas pendidikan, sama halnya dikemukakan oleh Darmawan 
Edutech, Tahun 13, Vol.1, No.2, Juni 2014

(2013:44). "the importance of school quality to prepare young generation who has excellent attitude, smart, independent, creative, innovative and democratic in line with the social change acceleration as a part of global era”. Maksudnya melalui kualitas sekolah yang baik maka akan terwujud generasi yang creatif, inovatif dan cerdas dalam menghadapi perubahan jaman terutama era globaliasi sekarang, karena kompetensi pedagogik mampu menciptkan suasana pembelajaran yang menarik dan mendapatkan output yang cerdas.

Hal ini diperkuat oleh Sanjaya (2009:279) bahwa kompetensi pedagogik merupakan kemampuan guru dalam pengelolaan pembelajaraan peserta didik yang sekurang-kurangnya meliputi:

a. Pemahaman wawasan atau landasan pendidikan

b. Pemahaman terhadap peserta didik

c. Pengembangan

kurikulum/silabus
d. Perangcangan pembelajaran
e. Pelaksanaan pembelajaran yang mendidik dan dialogis

f. Pemanfaatan teknologi pembelajaran

g. Evaluasi hasil belajar

h. Pengembangan peserta didik untuk mengaktualisasikan berbagai potensi yang dimilikinya

Berdasarkan hasil penelitian dan merujuk pada pendapat Mulyasa (2007:136) tentang kompetensi pedagogik maka dapat ditarik benang merah dalam penelitian ini bahwa terdapat pengaruh yang signifikan antara kompetensi pedagogik guru terhadap hasil belajar peserta didik.

2. Pengaruh Pembelajaran Kooperatif Berbantuan Media Presentasi yang Disampaikan oleh Guru terhadap Hasil Belajar Peserta Didik

\begin{tabular}{lr}
\multicolumn{1}{c}{ Berdasarkan } & hasil \\
perhitungan & dengan \\
menggunakan analisis & regresi
\end{tabular}

297 Pengaruh Kompetensi Pedagogik Guru Dalam Menerapkan Pembelajaran Kooperatif Berbantuan Media Presentasi Terhadap Hasil Belajar Peserta Didik Pada Mata Pelajaran Matematika 
Edutech, Tahun 13, Vol.1, No.2, Juni 2014

dan path analisys, koefesien jalur variabel pembelajaran kooperatif terhadap hasil belajar peserta didik sebesar 0,646 dan dengan teknik yang sama didapat persamaan regresi $\hat{Y}=-1,111+0,067 \mathrm{X}_{2}$.

Hasil analisis statistik tersebut memberikan gambaran betapa besarnya pengaruh pembelajaran kooperatif terhadap hasil belajar peserta didik dengan koefesien korelasi sebesar 0,646 , artinya semakin sering pembelajaran kooperatif dilakukan maka semakin tinggi hasil belajar peserta didik dan sebaliknya jika pembelajaran yang dilakukan berupa pembelajaran konvensional (non kooperatif) maka tingkat keberhasilan pembelajaran tidak maksimal, sehingga jelas sekali bahwa terdapat pengaruh yang signifikan antara pembelajaran kooperatif terhadap hasil belajar peserta didik.

Lebih jelas dikemukakan oleh Isjoni (2010:86-87) dalam cooperatif learning siswa atau peserta didik lebih mudah menemukan dan memahami konsep-konsep yang sulit apabila mereka saling mendiskusikan masalah-masalah tersebut dengan temannya. Masih menurut Isjoni (2010:96) hasil percobaan mengindikasikan bahwa cooperatif learning dapat meningkatkan keinginan kelas, prestasi yang dipertahankan, dan prestasi aktual. Artinya sebuah pembelajaran yang efektif, efisien, kolaboratif, interaktif dan menyenangkan dalam hal ini pembelajaran kooperatif dapat memberikan dampak positif terhadap ketercapaian prestasi belajar.

Pendapat yang sama dikemukakan oleh Deutsch, (1949) dalam Slavin, (2010:35) di dalam kelas yang kooperatif murid yang berusaha keras, selalu hadir di kelas, dan membantu yang lainnya belajar akan dipuji dan didukung oleh teman satu timnya. Artinya melalui pembelajaran kooperatif akan terciptanya suasana saling bantu antar peserta didik dan berdampak pada 
Edutech, Tahun 13, Vol.1, No.2, Juni 2014

$\begin{aligned} & \text { meningkatnya } \\ & \text { kemampuan dasar }\end{aligned}$ peserta
didik sehingga
disimpulkan $\quad$ bahwa
pembelajaran kooperatif yang
disampaikan oleh guru yang
memiliki kompetensi
pedagogik tinggi akan
memberikan pengaruh yang
signifikan terhadap hasil
belajar peserta didik, ini
sesuai dengan hasil penelitian
yang menunjukan sebesar
$41,8 \%$ hasil belajar peserta
didik dipengaruhi oleh
pembelajaran kooperatif.

Pengaruh pembelajaran kooperatif terhadap hasil belajar peserta didik yang besarannya berkisar $41,8 \%$ sesuai dengan hasil penelitian yang dikemukakan oleh Slavin (2010:44) secara keseluruhan, efek pembelajaran kooperatif terhadap pencapaian prestasi jelas positif, enam puluh empat (64\%) dari sembilan puluh sembilan perbandingan eksperimen-kontrol secara signifikan lebih menyukai pembelajaran kooperatif, khusus pada mata pelajaran matematika pembelajaran kooperatif memberikan efek yang menunjunkan angka $+1,04^{*}$ (penelitian dilakukan di Israel oleh Mavarech (1985b)

3. Pengaruh Media Presentasi yang Disampaikan oleh Guru dalam Pembelajaran Kooperatif terhadap Hasil

\section{Belajar Peserta Didik}

Dari hasil penelitian maka, hipotesis yang diterima pada penelitian ini adalah terdapat pengaruh yang signifikan antara media presentasi terhadap hasil belajar peserta didik, ini dilihat dari hasil pengolahan statistik dengan analisis jalur dan regresi mendapatkan nilai koefesien jalur sebesar 0,586 dan persamaan regresinya $\hat{Y}=$ - $1,119+0,069 X_{3}$. Artinya sebanyak 0,069 hasil belajar peserta didik akan naik apabila terjadi peribahan nilai $\mathrm{X}_{3}$ sebesar satu satuan sehingga media presentasi yang disampaikan oleh guru dalam pembelajaran kooperatif sangat memberikan arti positif terhadap peningkatan hasil belajar. 
Edutech, Tahun 13, Vol.1, No.2, Juni 2014

Hasil penelitian ini sesuai dengan hasil penyelidikan Ronald G. Held dalam Sundayana (2013:199) menyebutkan bahwa seorang peserta didik yang belajar dengan memakai indera pendenganran saja, maka settelah 3 jam dia mampu mengingat $70 \%$ dan setelah 3 hari kemudian dia hanya mampu mengingat $10 \%$ dari apa yang didengar, tetapi apabila seorang peserta didik belajar dengan menggunakan indera pendengaran dan penglihatan, maka setelah 3 jam dia mampu mengingat $85 \%$ dan setelah 3 hari dia masih mengingat $65 \%$ dari apa yang dia dengar dan lihat dan hasil ini diperkuat oleh Warsita (2008:30) Media Presentasi mempunyai potensi tinggi dalam penyampaian pesan maupun kemampuannya dalam menarik minat dan perhatian peserta didik, terbukti memiliki kemampuan yang efektif (penetrasi lebih dari $70 \%$ ) untuk menyampaikan informasi, hiburan, dan pendidikan.
Dari berbagai pendapat di atas dapat disimpulkan bahwa sebuah pembelajaran berbantuan media presentasi dapat meningkatkan hasil belajar peserta didi jika pembelajaran berbantuan media presentasi tersebut disampaikan oleh guru yang memiliki kompetensi pedagogik.

\section{Pengaruh Kompetensi}

\section{Pedagogik Guru,}

Pembelajaran Kooperatif

dan Media Presentasi terhadap Hasil Belajar Peserta Didik

Dari hasil analisis jalur dan regresi, koefesien jalur variabel kompetensi pedagogik guru, pembelajaran kooperatif dan media presentasi terhadap hasil belajar peserta didik sebesar 0,736 dengan persamaan regresi $\hat{Y}=-4,156+0,023 X_{1}$ $+0,035 \mathrm{X}_{2}+0,036 \mathrm{X}_{3}$.

Pengaruh yang diberikan oleh kompetensi pedagogik guru saja terhadap hasil belajar peserta didik pada penelitian ini sangatlah signifikan, ditunjukan dengan nilai kontribusi sebesar 27,1\% 
Edutech, Tahun 13, Vol.1, No.2, Juni 2014

ini sesuai dengan pendapat Darling-Hammond (1999: 12) "a $1 \%$ increase in teacher quality (as measured by NTE scores) was associated with a 3 to $5 \%$ decline in the percentage of students failing the exam", maksudnya adalah peningkatan kompetensi guru akan mengakibatkan menurunnya kegagalan dalam ujian, artinya1\% kompetensi pedagogik guru meningkat, maka $3-5 \%$ terjadi penurunan kegagalan dalam ujian.

Selain kompetensi pedagogik guru, hal lain yang berpengaruh terhadap hasil belajar peserta didik adalah pembelajaran kooperatif, dimana hasil penelitian menunjukan pembelajaran kooperatif memberikan pengaruh yang signifikan terhadap hasil belajar peserta didik dengan nilai $r$ sebesar 0,646 pada nilsi Sig $=0,000<$ $\alpha=0,05$ dan hasil ini sesuai dengan pendapat Felder \& Brent (2007:6) yang menyatakan "The use of collaborative methods had significant positive effects on understanding science and technology, analytical skills, and appreciation for diversity, among other outcomes" pendapat tersebut menyebutkan metode colabotaif (pembelajaran kooperatif) memberikan efek positif secara signifikan terhadap pemahaman sain dan teknologi, analisis kemampuan dan penerimaan terhadap pendapat orang lain sehingga berdampak pada meningkatnya hasil belajar (out come).

Tidak kalah pentingnya, dalam penelitian ini memberikan gambaran tentang hebatnya media presentasi yang mempengaruhi hasil belajar peserta didik, sampai $34,4 \%$ hasil belajar peserta didik dipengaruhi secara signifikan oleh pembelajaran yang menggunakan media presentasi. Penulis mengasumsikan tentang besarnya pengaruh yang diberikan media presentasi terhadap hasil belajar peserta didik dikarenakan. Pertama, media presentasi 
Edutech, Tahun 13, Vol.1, No.2, Juni 2014

memudahkan menyampaikan materi pembelajaran sehingga peserta didik mudah mencerna materi yang disampaikan oleh guru dalam pembelajaran kooperatif. Kedua, media presentasi merupakan alat bantu bagi siswa dalam memahami sebuah kondisi/kejadian pembelajaran yang disampaikan oleh guru dalam pembelajaran kooperatif. Ketiga, media presentasi dapat meningkatkan minat dan motivasi belajar peserta didik sehingga berakibat meningkatnya prestasi atau hasil belajar peserta didik.

Hasil penelitian ini
sesuai dengan pendapat
Sundayana (2013:32)
Media pembelajaran atau
media presentasi adalah
segala sesuatu yang dapat
digunakan menyalurkan
informasi dari guru ke siswa
sehingga dapat merangsang
pikiran, perasaan, perhatian
dan minat siswa dan pada
akhirnya dapat menjadikan
siswa melakukan kegiatan
belajar. Manfaatnya adalah
penyampaian materi dapat
diseragamkan,

pembelajaran menjadi jelas dan menarik, meningkatkan kualitas hasil belajar siswa.

Menurut Warsita (2008:262). Media presentasi merupakan bagian dari media pembelajaran sebagai salah satu unsur dari sumber belajar yang dapat dimanfaatkan untuk meningkatkan kualitas proses pembelajaran. Tetapi terdapat syarat utama media presentasi bisa berpengaruh secara signifikan terhadap hasil belajar peserta didik yaitu salah satunya adalah user atau guru sebagai operator dalam menjalankan media presentasi harus menguasai dan mampu memanfaatkan teknologi pembelajaran sementara kemampuan pemanfaatan teknologi hanya terdapat pada kompetensi pedagogik saja sehingga mutlak bagi guru harus memiliki kompetensi pedagogik apabila menginginkan sebuah pembelajaran dibantu oleh media presentasi.

Penelitian ini mencoba mengungkap besarnya pengaruh kompetensi 
Edutech, Tahun 13, Vol.1, No.2, Juni 2014

pedagogik guru dalam

menerapkan pembelajaran

kooperatif berbantuan media

presentasi terhadap hasil

belajar peserta didik pada

mata pelajaran matematika

dan hasil penelitian didapat

kontribusi masing-masing

variabel seperti telah

diuraikan di atas yaitu sebesar

$27,1 \%$ dari kompetensi

pedagogik, $41,8 \%$ dari

pembelajaran kooperatif,

$24,4 \%$ dari media presentasi

dan apabila semua variabel

diakumulatifkan

atau

bersama-sama maka didapat

pengaruh sebesar $54,2 \%$.

Artinya kompetensi

pedagogik guru dalam

menyampaikan materi melalui

pembelajaran kooperatif

berbantuan media presentasi

akan memberikan kontribusi

sebesar $54,2 \%$ terhadap hasil

belajar peserta didik.

Hasil penelitian ini sesuai dengan pendapat Ruseffendi yang

mempengaruhi keberhasilan

belajar peserta didik dalam

belajar adalah penyajian

materi, pribadi guru, suasana
Dari pendapat itu terdapat tiga poin penting yang menjadi catatan penulis. Pertama, penyajian materi mempunyai peran penting dalam keberhasilan belajar peserta didik maka dari itu penyajian materi harus semenarik mungkin sehingga peserta didik lebih tertarik untuk belajar dan salah satu cara mengemas materi pembelajaran supaya menarik adalah dengan menggunaka media presentasi. Kedua, suasana belajar yang tercipta sebisa mungkin berorientasi pada aktivitas peserta didik yang salah satu konsep tersebut terdapat pada pembelajaran kooperatif. Ketiga, kompetensi guru yang mampu menerapkan pembelajaran kooperatif berbantuan media presentasi adalah kompetensi pedagogik.

Akhirnya, penelitian ini dapat disimpulkan bahwa kompetensi pedagogik guru dalam menerapkan pembelajaran kooperatif berbantuan media presentasi memberikan pengaruh positif

belajar, dan kompetensi guru. 
Edutech, Tahun 13, Vol.1, No.2, Juni 2014

dan signifikan terhadap hasil belajar peserta didik

\section{SIMPULAN}

\section{Kesimpulan}

Berdasarkan hasil penelitian dan pembahasan, maka dapat ditarik kesimpulan sebagai berikut.

a. Terdapat pengaruh yang signifikan antara kompetensi pedagogik guru terhadap hasil belajar peserta didik, artinya semakin tinggi kompetensi pedagogik guru semakin tinggi hasil belajar peserta didik dan besarnya pengaruh variabel kompetensi pedagogik terhadap hasil belajar peserta didik tergolong kuat.

b. Terdapat pengaruh yang signifikan antara pembelajaran kooperatif terhadap hasil belajar peserta didik, artinya model pembelajaran kooperatif dilaksanakan dengan baik maka hasil belajar peserta didik akan tinggi dan besarnya pengaruh pembelajaran kooperatif terhadap hasil belajar peserta didik tergolong kuat

c. Terdapat pengaruh yang signifikan antara media presentasi terhadap hasil belajar peserta didik, artinya materi pembelajaran yang disampaikan melalui bantuan media presentasi dapat meningkatkan hasil belajar peserta didik dan besarnya pengaruh media presentasi terhadap hasil belajar peserta didik tergolong kuat.

d. Terdapat pengaruh yang signifikan antara kompetensi pedagogik guru, pembelajaran kooperatif dan media presentasi terhadap hasil belajar peserta didik, artinya pembelajaran kooperatif berbantuan media presentasi yang disampaikan oleh guru yang memiliki kompetensi pedagogik tinggi berakibat tingginya hasil belajar peserta didik dan besarnya pengaruh kompetensi pedagogik, pembelajaran kooperatif dan media presentasi terhdap hasil belajar peserta didik tergolong kuat.

\section{Saran}

Berdasarkan kesimpulan dari hasil penelitian ini dan upaya dalam meningkatkan hasil belajar peserta didik di SMA Ma'arif Peundeuy, maka direkomendasikan.

a. Kepada semua lebaga pendidikan terutama Perguruan Tinggi supaya membentuk budaya mendidik demi terciptanya sumberdaya manusia yang berkualitas, sehingga berdampak kepada hasil belajar yang sesuai dengan harapan sebagai bentuk kualitas layanan pembelajaran kooperatif.

b. Perguruan Tinggi sebagai bagian yang menyentuh langsung kepada 
Edutech, Tahun 13, Vol.1, No.2, Juni 2014

pembentukan karakter guru yang diharapkan bangsa dan negera seyogyanya menciptakan culture transfer knowlarge, sehingga kompetensi pedagogik guru bisa terwujud demi keberlangsungan suasana belajar yang menyenangkan.

c. Guru sebagai tulang punggung sekaligus tangan kanan dari keberlangsungan proses pembelajaran khususnya dan proses pendidikan umumnya. Guru terlibat langsung dalam proses pembelajaran yang terjadi secara terus menerus selama kontrak kurikulum terus berlangsung. Dalam upaya meningkatkan hasil belajar guru haruslah mengupayakan proses pembelajaran berlangsung secara efektif dan efisien serta melibatkan peserta didik seutuhnya, maka yang terlibat dalam proses pembelajaran hendaknya didinamiskan secara baik. Guru hendaknya mampu mewujudkan perilaku belajar peserta didik melalui interaksi pembelajaran yang interaktif, komunikatif, dan kooperatif dalam situasi pembelajaran yang kondusif. Semua itu memerlukan sumberdaya manusia (guru) yang berkompeten dalam mengupayakan mewujudkannya dan salah satu cara untuk mencapai hasil belajar peserta didik yang tinggi harus dimulai dari kompetensi pedagogik guru yang tinggi. Karena guru yang memiliki kompetensi tinggi akan mampu meningkatkan kualitas pembelajaran melalui berbagai strategi, model dan metode pembelajaran terbaru yang sesuai dengan karakteristik peserta didik dimana salah satu cara untuk meningkatkan hasil belajar melalui penerapan pembelajaran kooperatif.

d. Kepada satuan pendidikan dalam rekrutmen guru hendaknya melihat dan memperhatikan indikatorindikator kompetensi terutama aspek-asek penting penguasan guru terhadap kompetensi pedagogik. Hal ini sangat penting guna peningkatan kuaitas layanan pembelajaran demi memuaskan warga pendidikan terutama peserta didik.

e. Untuk peneliti dibidang Teknologi Pendidikan hendaknya memperhatikan aspek kompetensi guru dalam bidang keterampilan mengajar dan media pembelajaran yang tepat digunakan dalam menyampaikan materi pembelajaran, diharapkan penelitian ini bisa dijadikan alternatif pemecahan masalah yang relevan dimana kompetensi pedagogik guru dalam menerapkan pembelajaran 
Edutech, Tahun 13, Vol.1, No.2, Juni 2014

kooperatif berbantuan media presentasi bisa diterapkan dalam penelitian berikutnya.

f. Untuk mendapatkan hasil belajar yang baik perlu diperhatikan dalam proses pembelajaran yang tentunya harus menarik, efektif dan efisien melalui pembelajaran kooperatif serta untuk memudahkan menyampaikan materi pembelajaran dibutuhkan bantuan media berupa media presentasi, pembelajaran kooperatif berbantuan media presentasi bisa dilakukan jika dilaksanakan oleh guru yang memiliki kompetensi pedagogik, sehingga wajib bagi semua guru memiliki kompetensi pedagogik supaya pembelajaran kooperatif berbantuan media presentasi bisa dilaksanakan dengan baik dan berdampak pada hasil belajar yang memuaskan.

\section{DAFTAR PUSTAKA}

Ariani, N. dan Haryanto, D., (2010) Pembelajaran Multi Media di Sekolah. Jakarta. PT. Prestasi Pustakaraya.

Arikunto, S., (2004). Prosedur Penelitian Suatu Pendekatan Praktek. Jakarta: Rineka Cipta.

Candra, C. dan Zakaria, T. M., (2010). Be Smart, Be Profesional with
Microsoft Office 200. Bandung: Informatika.

Darling, L. D., (1999). Teacher Quality and Student Achievement: A Review of State Policy Evidence. Center for the Study of Teaching and Policy. University Of Washington

Darmawan, D., (2013). Metode Penelitian Kuantitatif. Bandung. PT. Remaja Rosdakarya.

Darmawan, D., (2012). Inovasi Pendidikan: Pendekatan Praktik Teknologi Multimedia dan Pembelajaran Online. Bandung. PT. Remaja Rosdakarya.

Darmawan, D., ET AL. (2013). Video Streaming for Creative Writing at International Elementary School. Dalam Google Cendikia (online), Vol 7 (1) pp. 43 - 56, 14 halaman. Tersedia:

http://scholar.google.com/citations? hl=id\&user=kwq6WCMAAAAJ\&vi ew_op=list_works

Felder, M. R. and Brent, R., (2007). Cooperative Learning: Departmen Of Chemical Engineering, N.C. State University Raleigh, NC 27695-7905. Education Designs, Inc., Cary, NC 27518

Ibrahim, M., Et al., (2000). Pembelajaran Kooperatif. Surabaya: University Press. 
Edutech, Tahun 13, Vol.1, No.2, Juni 2014

Iskandar, (2005). Metodologi Penelitian. Jakarta: Rineka Citra.

Majid, A., (2006). Perencanaan Pembelajaran Mengembangkan Standar Kompetensi Guru. Bandung. PT. Remaja Rosdakarya.

Mayer, E. R., (2009). Multi Media Learning prinsip-prinsip dan aplikasi. Yogyakarta. Pustaka Pelajar.

Mulyasa, E., (2001). Kurikulum Berbasis Kompetensi. Bandung: PT Remaja Rosdakarya.

Mulyasa, E., (2007). Standar Kompetensi dan Sertifikasi Guru. Bandung: PT Remaja Rosdakarya.

Ninggar, D., (2011). PowerPoint 2010 untuk Orang Awam. Palembang: Maxikom.

Nugroho, B. A., (2005). Strategi Jetu Memilih Metode Statistik Penelitian dengan SPSS. Yogyakarta. Andi.

Quthb, A. M. S., (2005). Amal Shaleh Pengantar ke Surga dan Penyelamat dari Neraka, Jakarta Timur. Pustaka al-Kautsar.

Rasyid, H. dan Mansur., (2009). Penilaian Hasil Belajar: seri pembelajaran efektif. Bandung. CV Wacana Prima.

Ruseffendi, E. T. (1991). Pengantar Kepada Guru Mengembangkan Kompetensinya dalam Pengajaran
Matematika untuk Meningkatkan

CBSA. Bandung. Tarsito

Sanjaya, W., (2006). Strategi Pembelajaran Berorientasi Standar Proses. Jakarta. Kencana Prenada Media Group.

Sanjaya, W., (2013), Penelitian Pendidikan. Jakarta: Kencana, Prenada Media Group.

Slavin, R. E., (1995). Cooperative learning. Theory, Research and Practice, Second Edition. Boston: Allyn and Bacon.

Sudjana, N., (2004). Dasar-dasar Proses Belajar Mengajar. Bandung : Sinar Baru Algensido Offset.

Sukmadinata, N. S., (2005). Metode Penelitian Pendidikan. Bandung. PT. Remaja Rosdakarya.

Sugiyono. (2009). Metode Penelitian Pendidikan Pendekatan Kuantitatif, Kualitatif, dan $R \& D$. Bandung: Alfabeta.

Sundayana, R., (2010). Statistika Penelitian Pendidikan. Garut : STKIP Garut Press.

Sundayana, R., (2013). Media Pembelajaran Matematika: (untuk guru, calon guru, orang tua dan para pecinta matematika). Bandung : Alfabeta.

Syah, M., (2004), Psikologi Pendidikan dengan Pendekatan Baru. Bandung: Remaja Rosdakarya. 
Trianto, (2009). Mendesain Model

Pembelajaran Inovatif-Progresif.

Jakarta. Kencana Prenada Media

Group.

Usman, U., (2002). Menjadi Guru

Profesional. Bandung. PT. Remaja

Rosdakarya.

Wahyudin, U. ET AL., (2013). Developing

Image of Higher Education

Performance. Dalam Google scholar (online), vol 6 (6, 7 halaman.

Tersedia:http://scholar.google.co.id/

citations?view op=view citation\&h

l=id\&user=kwq6WCMAAAAJ\&cit

ation for view=kwq6WCMAAAAJ

:mB3voiENLucC (4 Juni 2014)

Wilkel, W.S., (1996). Psikologi

Pengajaran. Jakarta: Gramedia

Widiasrana Indonesia.

(2012). Pedoman Penulisan

Tesis. Program Studi Teknologi

Pembelajaran. Program Pasca

Sarjana. STKIP Garut.

UU Nomor 20 tahun 2003 tentang Sistem

Pendidikan Nasional

UU Nomor 14 tahun 2005 tentang Guru dan Dosen

PP no. 19 Tahun 2005 tentang Standar Nasional Pendidikan

Keputusan Menteri Pendidikan Nasional

no. 045/U/2002 tentang Dewan

Pendidikan dan Komite Sekolah

308 Pengaruh Kompetensi Pedagogik Guru Dalam Menerapkan Pembelajaran Kooperatif Berbantuan Media Presentasi Terhadap Hasil Belajar Peserta Didik Pada Mata Pelajaran Matematika 